\title{
일본 동료검토(peer review) 회의 결과
}

일본 동료검토회의가 2010. 5.19(목) OECD회의장에서 개최되었다. 금번 동료검토회의에서는 $\mathrm{DAC}$ 사무국의 "일본 동료검토 주요결과 및 권고(안)" 을 기초로 일본 특별대표단과 DAC 회원국 들 간의 질의응답 형태로 진행하였고, 동 회의의 주요내용을 아래와 같이 보고하였다.

\section{I. 핵심 요지}

\section{가. 일본 수석대표 모두발언}

일본측 수석대표로 참석한 Mr.Kazuo SUNAGA 외무성 국제협력국 부국장은 2003년 동료검토를 계기로 그간 일본정부는 ODA 정책 및 집행체계에 대한 지속적인 개선작업을 실시해 왔다고 설명하 면서, 특히 New JICA 발족을 통한 집행체계 통합 및 간소화와 외교부 개발협력국 및 JICA의 조직 개편(국별지원체제로의 전환)은 대표적인 성과라고 언급함.

아울러, 일본 원조의 주요 정책방향으로, (1)수원국의 주인의식(ownership) 존중, (2) 경제성장을 통한 빈곤감소, (3)ODA에 대한 국민적 지지확보를 위한 원조의 가시성(visibility) 제고, (4)Non$\mathrm{DAC}$ 공여국 및 신흥 공여국과의 협력 확대, (5)NGO와의 협력강화 등을 제시함.

\section{나. 개발협력체계 일반}

회원국들은 일본이 지난 2003년 동료검토 이후 개발협력체계 전반에 걸친 괄목할 만한 개선을 이 루었다고 평가하면서, 특히 New JICA의 출범을 통한 집행효율화 및 시너지 제고 효과에 대해 높 은 관심을 나타냄. 단, 개발을 위한 정책일관성 $(\mathrm{PCD})$ 제고를 위해서는 정책문서화, 부처간 정책조 정 메커니즘 강화, $\mathrm{PCD}$ 모니터링 능력향상 등의 노력이 필요함을 권고함. 이에, 일본측은 하토야 마 신정부는 동 이슈의 중요성을 잘 인식하고 있으며 현재 정부부처간 논의가 진행 중임을 밝힘. 


\section{다. 원조 규모, 채널 및 배분}

일본 peer review에 참여한 examiner들은 최근에 일본의 원조규모가 확대되고 있지만 ODA/GNI 가 여전히 권고수준인 $0.7 \%$ 는 물론이고 $\mathrm{DAC}$ 회원국 평균( $0.31 \%)$ 에도 미치지 못함을 지적하였으 며, 일부 회원국들은 일본이 보다 구체적이고 책임성 있는 $\mathrm{ODA}$ 증대계획을 제시할 것을 권고함.

원조 채널과 관련하여, 일본 ODA가 원조의 가시성(visibility) 확보가 상대적으로 용이한 양자지원 의 비중이 매우 높고, 다자지원의 경우에도 non-core (ear-marked) 형태의 기여에 초점을 맞추 고 있는데 대해 회원국들은, core contribution형태의 다자지원도 궁극적으로 해당 국제기구에서 의 기여도 및 영향력을 제고시켜 가시성 확보에 도움이 될 수 있다는 의견을 제시함.

동 세션에서 제기된 다양한 질의와 권고에 대한 답변을 통해 일본 대표단은 (1)아프리카 지역의 $\mathrm{MDG}$ 달성지원 강화를 중심으로 $\mathrm{ODA}$ 규모를 확대해 나갈 예정임, (2)원조 예측성관련, 단년도 예 산시스템을 보완하기 위해 국별 rolling plan을 수립하고, 엔차관의 경우 수원국과 다년간 협정 체결, (3)고채무빈국에 대해서는 유상원조를 지원하지 않음, (4)대부분의 다자지원의 경우 core contribution 방식으로 지원하고 있으며, 다만 UNHCR, WFP 등 일부 긴급구호 관련 다자지원의 경우 사업의 특성상 non-core contribution의 비율이 높음. (5)유· 무상 연계와 관련하여, 프로그 램에 기반한 접근방식 $(\mathrm{PBA})$ 을 근간으로 원조방식간 조화에 초점을 두고 있음과 아프리카는 MDGs 촉진에 적합한 무상원조 중심, 중 - 저소득국의 경우 유- 무상을 포괄하여 개발과제 해결을 위한 최 적의 modality를 구성하여 활용하고 있음을 설명함.

\section{라. 조직 및 운영}

동 세션에서 회원국들은 New JICA의 발족을 통한 원조체계의 통합 및 간소화 등에 따른 성과 및 시너지 효과에 대한 깊은 관심을 표시했으며, 아울러 개편된 체제하에서의 정책-실행 간의 연계 및 역할분담, 현장중심 및 분권화 추진현황, 평가 및 모니터링 시스템 등에 대한 일본 측의 설명을 요 청함.

일본 대표단의 설명에 따르면, New JICA 설립의 효과는 크게 유·무상원조의 통합적 운영을 통한 전략적 연계강화와 JICA의 집행자율성 확대에 따른 사업추진절차 효율화로 나타남. 사업현장에서 유-무상별로 개별적으로 실시되던 사업발굴 및 현장조사가 통합적으로 진행됨에 따라 전반적인 사업추진절차가 간소화되었으며, 다양한 사업수단 및 형태를 연계하여 특정 개발과제 해결에 필요 한 최적의 구성을 마련할 수 있는 가능성이 높아짐. 
$\mathrm{ODA}$ 집행과 관련한 New JICA의 책임과 자율성을 대폭 확대함에 따라 단위사업의 추진절차가 이 전에 비해 약 6 개월 정도 단축되었으며, 외무성-JICA 간의 역할분담이 보다 명확하게 되어 오히려 상호 의견교환이 활성화됨.

분권화 관련, 구체적인 현장인력의 비율을 정하지는 않고 있으나 지속적으로 현지파견 및 권한의 현장위임을 확대해 나갈 예정이며, 현지직원 활용 및 역량강화를 중점 추진하고 있음.

원조사업에 대한 평가는 일본국민과 정부에 대한 책임성을 제고시켜 궁극적으로 $\mathrm{ODA}$ 에 대한 지지 를 확보할 수 있는 중요한 수단으로 인식하고 있으며, 객관적인 평가를 위해 외부전문가와 수원국 정부를 적극적으로 참여시키고 있음.

\section{마. 원조효과성}

회원국들은 $\mathrm{PD} / \mathrm{AAA}$ 이행노력과 관련하여, 일본이 특히 원조조화(공동조사, pool fund 조성 등) 및 untying에 있어서 다소 소극적인 자세를 보이고 있다고 평가하며 이에 대한 입장과 향후 개선방 향을 제시해 줄 것을 요청함.

일본이 2008년 untying 비율을 $84 \%$ 로 보고했으나 양자 ODA의 $13 \%$ 에 대한 untying 여부를 보고 하지 않았으며, 주계약자(Primary Contractor)를 일본기업으로 하고 하청을 국제(현지)입찰로 선 정하는 경우도 untying으로 계상하고 있는 것에 대한 지적에 대해 일본 대표단은, (1)untying과 관 련하여 국제적 합의를 존중하고 확대노력을 지속하고 있지만 (2)개도국에서 일본 기업의 기술을 특 별히 요청하는 경우도 untying 대상으로 획일적으로 적용하는 것은 무리이며 (3)원조사업이 단순 서비스 전달을 넘어 현지의 기술역량 강화에 기여하는 바가 큰 점을 고려할 때 공개입찰을 통해 주 계약자를 선정하는 것이 비효율적일 수 있으며, (4)untying 확대에 따른 국내 ODA 지지기반 축소 는 $\mathrm{ODA}$ 규모확대에 부정적 영향을 미칠 수 있으며 (5)일본은 untying-원조효과성 간의 직접적 연 관성에 대한 회의적 시각도 있음을 설명함.

일본의 적극적 삼각협력 추진전략에 대해, 멕시코 대표는 중저소득국 전문가를 활용한 삼각협력 확 대를 제안하였으며, 스페인은 브라질 및 멕시코 등과 연계한 중남미 지역에서의 삼각협력의 성과 및 교훈에 대해 문의함. 


\section{바. 인도적지원}

포르투갈 대표는 인간안보(human security) 증진을 목표로 하는 일본의 ODA가 인권문제 등을 포 함한 거버넌스 이슈에 대해서는 소극적인 이유와 최근 $\mathrm{ODA}$ 와 관련한 자위대 활동의 증가로 인한 군사적 개입의 위험성에 대해 문의함.

일본 측은, 개발에 있어서 경제성장을 우선시하는 아시아적 관점에서 거버넌스 이슈에 대한 시각은 서구 국가들과 다소간 차이가 있을 수 있음을 언급함. 자위대 파견과 관련해서는, 군병력의 해외파 견은 매우 조심스럽게 접근하고 있으나 신정부의 시책에 의해 아이티 지진 등 해외긴급재난구호와 $\mathrm{UN}$ 평화유지활동 등에 보다 효율적으로 대처하기 위해 외교부와 국방부가 긴밀히 협조하여 추진하 고 있음을 설명함.

\section{II. 관찰 및 건의}

금번 동료검토회의에서 제시된 일본 ODA에 대한 평가와 권고들은 일본과 유사한 $\mathrm{ODA}$ 정책 및 집 행체계를 가지고 있는 우리나라에 많은 시사점을 제공하고 있음. DAC 신규가입국으로써 2012년 최초로 동료검토를 수검해야 하는 우리나라의 입장에서는 일본 ODA에 대한 DAC사무국 및 회원국 들의 검토기준 및 주요 관심사항을 분석하여 $\mathrm{ODA}$ 선진화 추진시 반영할 필요가 있으며, 특히 최근 $\mathrm{DAC}$ 내에서 관심과 논의가 증대되고 있는 $\mathrm{PCD}$ 는 향후에도 동료검토의 주요 평가지표로 유지될 것 으로 전망되므로 관심을 강화해 나갈 필요가 있음.

특히, 우리나라의 경우에는 $\mathrm{DAC}$ 가입심사시 제시한 개선과제들(원조규모 확대, 원조집행체계 효율 화, 언타이드 등)에 대한 이행상황을 중심으로 동료검토가 진행될 가능성도 있으므로 동 과제들과 관련한 성과사례 확보방안 마련이 필요할 것으로 사료됨. 아울러, 우리나라도 $\mathrm{DAC}$ 회원국으로서 책 임과 역할을 분담하고 개발정책에 대한 분석능력 제고 등을 위해 2011년경 동료검토 주심사국으로 참여하는 방안을 적극 검토해 주시기를 건의함. 